\title{
The Obstacles of Indonesia-Iceland Cooperation In the Development of Geothermal Energy in Indonesia (2007-2014)
}

\section{Althea S Bestari, Novita Putri Rudiany}

Althea S Bestari

$\begin{array}{lll}\text { Affiliation } & : & \text { Universitas Pertamina } \\ \text { City } & : & \text { Jakarta } \\ \text { Country } & : & \text { Indonesia } \\ \text { Email } & : & \\ \text { altheabestari@gmail.com }\end{array}$

Novita Putri Rudiany

(Correspondence Author)

$\begin{array}{lll}\text { Affiliation } & : & \text { Universitas Pertamina } \\ \text { City } & : & \text { Jakarta } \\ \text { Country } & : & \text { Indonesia } \\ \text { Email } & : & \\ \text { vitarudiany.up@gmail.com }\end{array}$

History

Submission : 18 September 2020 Review : 30 November 2020 Completed

Accepted : 15 December 2020 Available : 22 December 2020

Online

DOI :

10.51413/jisea.Vol1.Iss2.2020.136-158

\section{Copyright}

This is an open access article distributed under the term of the creative commons attribution 4.0 international licence

\begin{abstract}
This paper discusses the obstacles in IcelandicIndonesian cooperation related to geothermal development in Indonesia in 2007 - 2014. In the cooperation process that prioritizes geothermal energy use in Indonesia, the interaction between Iceland and Indonesia has not shown significant implementation results, mainly technical geothermal energy exploration. This cooperation has been going on for seven years. The concept of Barriers to International Cooperation developed by Lauri Siitonen, which is a derivative of the idea from Theories of International Cooperation, is used to analyze existing obstacles. This concept explains why cooperation and obstacles can occur due to the interactions of the actors involved. In this case, each country's technical and administrative problems gave impacts on the program's discontinuation to technical cooperation. This research is based on primary data and secondary data with descriptiveanalytical methods. This paper's conclusion shows that political and policy factors and technical factors are significant in hindering this cooperation.
\end{abstract}

Key Words: Indonesia, Iceland, Geothermal, Bilateral Cooperation, Obstacles

\section{Cite this article :}

Bestari, A. S., \& Rudiany, N. P. (2020). The Obstacles of Indonesia-Iceland Cooperation In the Development of Geothermal Energy in Indonesia (2007-2014). Journal of International Studies on Energy Affairs, 1(2), 136-158. https://doi.org/10.51413/jisea.Vol1.Iss2.2020.136 - 158 


\section{INTRODUCTION}

The cooperative relationship between Indonesia and Iceland has been formed in the energy sector, significantly to develop geothermal energy. The progress of this cooperation has been agreed upon since 2007. However, the collaboration between the two countries has not shown any significance until 2014, especially in exploration activities. The cooperation was successful only in implementing the initial phase in 2016 by KS ORKA in collaboration with PT Sorik Marapi Geothermal Power in the Mandailing Natal area, North Sumatra (KS ORKA, 2019). This condition has been confirmed by REmap Analysis IRENA's that the development of the installed capacity of geothermal power in 2010 was $1.2 \mathrm{GW}$ to $1.4 \mathrm{GW}$ in 2014. In contrast, the initial target was set in 2014 to install 4,000 MW of 44 additional generators (IRENA, 2017). This issue is one of the biggest concerns regarding cooperation, as it just reached the stage of knowledge transfer. Meanwhile, the technical cooperation onstage joint exploration has not been carried out intensively.

Several activities related to research and development have been carried out. First, after the formation of the Memorandum of Understanding (MoU) in 2007, the Government of Iceland gave a mandate to UNU GTP (United Nations University Geothermal Program) Reykjavik to organize workshops for Indonesian geothermal specialists (Embassy of Indonesia, 2019). Second, organizing workshops on energy and mineral issues has also been carried out to improve the quality of Indonesia's human resources (HR) in geothermal science through organizing seminars, conferences, and others. But in the process, it has just been carried out through a workshop in 2017 by a delegation of the Indonesian Parliament, officials from the Ministry of Energy and Mineral Resources (ESDM) RI, directors of several BUMN and consulting service companies in the energy and infrastructure sector, along with the Indonesian ambassador to Iceland to Iceland. Another discussion was also held in 2017 as several delegations of the Indonesian Parliament had a visit to 
ISOR, known as the Iceland GeoSurvey, to be precise on 9 August 2017 to take a more in-depth approach Iceland's experience related to geothermal energy utilization (ÍSOR, 2017).

Although cooperation regarding geothermal energy development has been conducted since increasing the capacity building for Indonesian experts through education and, the signing of the MoU is considered a new momentum to intensify cooperation in the technology sector. However, technical implementation in geothermal projects was not realized until 2014. In response to this, the two countries agreed to carry out sustainable exploration activities at the cooperation level. In this case, the development of geothermal cooperation is an activity that must be studied continuously considering the geological differences of each country in the world.

In Iceland, the beginning of geothermal development began through an accidental event in 1907, precisely in Iceland's western region. A farmer has been known to discover this energy source until other farmers followed a trend, he created in the 1930s to expand to urban areas. The peak of geothermal energy utilization in Iceland then occurred in 1970, when the world's oil crisis-hit countries. This emergency condition triggered the Icelandic government to take a policy to start promoting the exploitation of geothermal resources to ensure its domestic needs. Uniquely, when the oil crisis ended in 1980 and other countries again switched to conventional natural resources, especially oil, but not Iceland. The government continues to develop geothermal energy as the primary energy resource, especially in electricity generation. The development of geothermal energy in Iceland, which has resulted in total success, has dramatically helped meet its domestic energy needs until now. The community's needs, such as heating, hot water baths, drying agricultural land and agricultural products, tourist attractions, and others, are fulfilled (KESDM, 2010).

Along with the advantages possessed by Iceland, on 12-13 September 2007, a forum was launched by the Embassy of the Republic of Indonesia (KBRI) in Oslo, Norway, in coordination with the Ministry of 
Industry, Energy and Tourism of Iceland and Reykjavik Energy Invest (REI) (Embassy of Indonesia, 2014). The forum specifically had the theme of the Indonesia-Iceland Geothermal Forum in Reykjavik, Iceland, and was attended by CEOs of companies from both countries in the energy sector. The existence of this forum has finally taken Iceland's attention to see Indonesia as a country with great geothermal potential. Furthermore, the Minister of Energy and Mineral Resources (ESDM) Indonesia, Dr. Purnomo Yusgiantoro, and Minister of Industry, Energy and Tourism of Iceland, Mr. Ossum Skarphedinsson, signed a Memorandum of Understanding (MoU) related to cooperation in the geothermal sector in Jakarta on 23 October 2007. The signing was also accompanied by signing cooperation contract between the President Director of PT PGE (Pertamina Geothermal Energy), Bambang Kustono, and REI represented by REI CEO Gudmundur Thoroddsson. The increase in cooperation was marked by a meeting at the World Geothermal Congress (WGC) on 30 April 2010, which was initiated by the International Geothermal Association and the Government of the Republic of Indonesia by the API) or the Indonesian Geothermal Association Indonesian Geothermal Association ((INAGA) in Nusa Dua, Bali (MEMR, 2010). During the meeting, Indonesian President Susilo Bambang Yudhoyono and Icelandic President Olafur Ragnarr Grimsson agreed to increase cooperation in geothermal energy development to establish a Geothermal Study Center, named Center of Excellence on Geothermal (Sukhyar, 2010). Unfortunately, a new partnership is only carried out normatively, namely by training experts and so on, even though the MoU has been described in article II regarding Areas of Cooperation (MoU, 2007). In point 4 of this MoU, the agreement's expected long-term goal is cooperation in the form of exploration, exploitation, and utilization of geothermal energy. The partnership has been agreed upon in the implementation or utilization stage of geothermal energy development in Indonesia. That way, if there has been an agreement technically, the implementation phase should have been carried out, or the community should have felt the benefits. 
Based on the explanation above, it can be seen that the development of cooperation in the practical realm in the form of exploration is still very minimal, while the MoU has been in effect since 2007. Therefore, this paper will answer the question related to the factors that become obstacles in Indonesia and Iceland's cooperation framework in the geothermal sector. In 2014, there were not many exploration projects held by two countries. This paper will be divided into four sections. The first part is an introduction. The second part is a theoretical framework that explains the barriers to bilateral cooperation within international cooperation. The second part is followed by a discussion of analysis related to case studies. The last part is the conclusion.

\section{METHOD}

To answer the research question, the author uses the concept of cooperation between countries, which specifically addresses the bilateral cooperation. According to Milner (1992), the idea of cooperation includes two essential elements. First, it has been assumed that each actor's behavior is directed by several goals, where each goal is not necessary to have the same purpose as the other related actors. Still, the point is that they assume rational behavior in their way. Second, the definition of cooperation has been applied in that cooperation has provided gains or rewards for actors. The gains do not have to be equal for each country, but the most important thing is that they are mutually beneficial. Each actor helps others achieve their goals or interests by making various policy adjustments to anticipate their rewards own. However, each actor does not always help the other because it is expected to improve the situation itself, leading to policy adjustments (Milner, 1992).

The things mentioned above have the potential to cause obstacles to international cooperation, especially in bilateral relations. The international system's anarchic nature has emphasized the state's egoistic behavior, namely the desire to maximize relative and absolute gain, in the end, tend to compete with each other. According to Grieco (1988), as a result, states that seek to maximize absolute individual gain, 
as well as a fraud that cannot be punished by respective countries, constitute the greatest obstacle to cooperation between countries. Meanwhile, Milner (1992) has stated that the state's structural conditions are more important than the problem of relative gain. If the profits generated are low, then the relative gain is essential, and cooperation is impossible because such situations create opportunities for countries to exploit the relative gains for their benefit. Barriers to the collaboration between countries stem from not being informed about the status, what the other party is doing, why it decided to do it, and what it might do in the future. Besides, the higher cost and risk of reaching and implementing agreements make it more difficult for countries to cooperate (Jervis, 1999). Actors are the leading players in bilateral cooperation, especially governments.

In particular, Lauri Siitonen (1990) explained that it is more challenging to define cooperation in social reality, especially in the case of international development, because it also summarizes intercultural issues. The issue of world mineral resources has provided an example of a new power factor in the international system, mostly related to development cooperation on problematic global mineral issues. Control over national mineral wealth and guaranteed access to raw materials will be the main criteria for collaboration among mineral producing and consuming countries. Interdependence between countries tends to raise new issues of global concern, such as maintaining stable economic growth or depleting world mineral reserves. In short, there are three criteria for cooperation, some of which can conflict with others and present barriers in themselves. The first is rational, which, if viewed from a national perspective, may not be reasonable from a global perspective. Second and third, efficiency global issues can turn out to be unequal (Siitonen, 1990).

On the other hand, actors and structures also hinder cooperation because only actors can make politics, even if they do so in a historically developed design (Siitonen, 1990). On the other hand, barriers to bilateral cooperation based on their classification are divided into seven categories (Caldés, Lechón, Rodríguez, \& Río, 2018), namely (i) 
Political and policy, (ii) Technical, (iii) Legal, (iv) Geopolitical, (v) Public revenue, (vi) Economy, and (vii) Environment. Within the seven factors, political and policy factors and technical factors can be said to have been considered the supporting elements that most influence the successful implementation of the cooperation mechanism. First, political and policy factors include two different, although related factors. On the one hand, political factors include issues related to cooperation mechanisms that are important to policymakers at the national, regional, or local level, which will influence their support or opposition to the cooperation mechanism, separately into politicaleconomic and political-environmental factors. Also, issues related to policy features (uncertainty about future policy frameworks, target ambitions, and design options for implementing cooperative mechanisms). Secondly, technical factors have been linked to technical limitations or supporting factors influencing the cooperation mechanism's successful implementation. This category includes improved systems management through the import of dispatchable electricity, possibilities to promote technology research and knowledge transfer, lack of market and network integration, challenges in calculating related indirect costs and benefits, etc. Operationally, these technical factors lead to technology gaps and technology transfer failures. This category includes a discussion of complexities such as improvements to the management system for transportable electricity imports, the absence of physical technology transfer, and the lack of market and network integration. This technical hindrance is explained in more detail through a mapping written by Adam Mazurkiewicz \& Beata Poteralska (2016) regarding the causes of technology transfer failure in large part. One is that technology is too sophisticated, making it difficult to change to make it suitable for production or market demands.

Meanwhile, organizational-economic barriers are the most frequently analyzed group of obstacles in the literature (Mazurkiewicz \& Poteralska, 2016). One of the broad spectra of borders is a considerable asymmetry condition between providers and recipients in terms of 
having different characteristics, such as skills, prices, cost contributions, internal structure, size, experience, etc. Simultaneously, other obstacles that are also relatively frequent are system barriers (Mazurkiewicz \& Poteralska, 2016). The blocks also include the absence of a nationallevel technology development plan. The public decision-making powers have been unable to support and targets public and private $R \& D$ and innovation. On the other side, lobbying or interest groups effectively inhibit change and improvement in the legal system, making technology transfer impossible or inefficient.

Based on this theoretical framework, it can be explained that the Indonesia-Iceland barrier is motivated by operationalization factors, especially in terms of the complexity of the regulations of the two countries and the absence of real technology transfer. Based on political and policy aspects and technical factors as determining factors for the main obstacles, Indonesia-Iceland cooperation obstacles can be identified from an internal (domestic) and external (international) perspective.

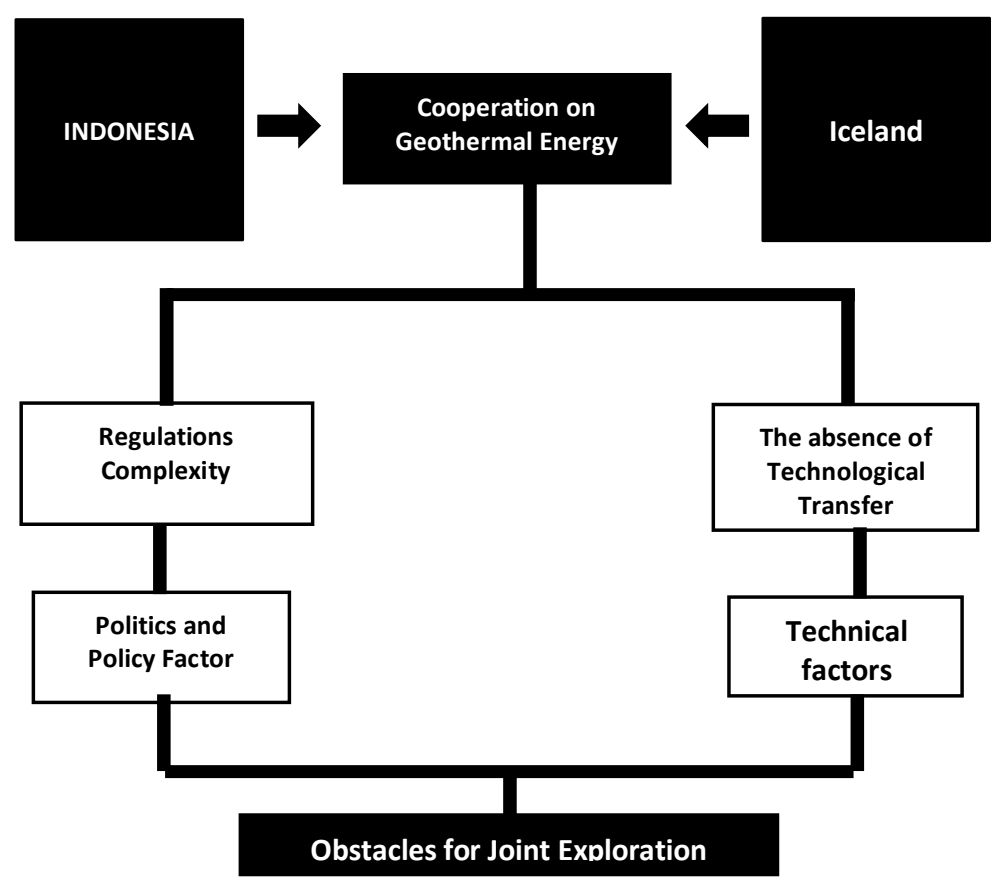

Fig 1. Theoretical Framework 
Cooperation between Indonesia and Iceland has been tied to bilateral collaboration that focuses on the geothermal sector. The analysis will focus on the discussion regarding the complexity of regulations in both countries and how these can mutually affect the smooth running of cooperation. Also, the second thing that is of concern is the absence of technology transfer in this cooperation. In general, two main obstacles influence the overall cooperation process, namely policy factors and technical factors. Thus, these two factors can explain the barriers to joint exploration because it will result in the discovery of disabilities in the cooperation based on cooperation development dynamics from 2007-2014.

This paper uses a qualitative descriptive-analytical research method. Several ways to collect data in this study are through primary data in interviews and secondary data. This research uses data validity checking techniques through triangulation techniques. We interviewed Mr. Sentot Yulianugroho as Manager of Government \& Public Relations from PT Pertamina Geothermal Energy to support the secondary data.

\section{RESULTS AND DISCUSSIONS}

\section{Alternative Energy Regulatory Systems in Indonesia and Iceland}

Geothermal energy sources are abundant as solutions to supply increased electricity production in Indonesia. Based on 2015 data in Indonesia Investments, Indonesia's geothermal energy has reached $40 \%$ of the world's total geothermal energy reserves, which is why Indonesia is estimated to have enormous geothermal energy resources in the world. However, the use of geothermal energy in Indonesia is still very minimal due to domestic energy. Indonesia only uses $4-5 \%$ of its geothermal capacity (International Geothermal Association, 2015). There are three main reasons for the use of alternative geothermal energy in Indonesia. First, the reality faced by Indonesia's dependency on fossil energy as the primary energy source will be unsustainable for 
the long-term national energy needs. Second, climate change has become the main focus of many countries, including Indonesia, to gradually follow-up on renewable energy policies to reduce fossil energy dependence. Third, concerning Indonesia's interest in developing geothermal potential, the regulation has been regulated in Presidential Decree Number 5 of 2006 concerning National Energy Policy by setting a target of the energy mix divided into $17 \%$ for renewable which $5 \%$ is from geothermal (Kabarbisnis, 2011).

Based on the three factors above, the Governments of Indonesia and Iceland see the potential that exists and sees the concept of international cooperation as one way to realize geothermal energy development in Indonesia. The interest in implementing international cooperation was finally proven by the initiative of the Indonesian delegation's visit to Iceland to agree on cooperation in the form of a Memorandum of Understanding (MoU) (KESDM, 2010). The collaboration between Indonesia and Iceland was officially decided on 23 October 2007. In responding to this interest, the government formulated regulations that have not accelerated national energy achievement programs as proclaimed by the government, which targets it in 2025, which hinders geothermal energy to be developed. The commitment of Indonesian President Susilo Bambang Yudhoyono that prioritizes reducing $\mathrm{CO} 2$ emissions by $26 \%$ by 2020 is now doubted (Meilani \& Wuryandani, 2010) because it has not been able to optimize the utilization and use of geothermal energy. The government's performance has disappointed the Indonesian people with various shreds of evidence that have not implemented the Master Plan for the Acceleration of Expansion of Indonesian Economic Development $(\mathrm{MP} 3 \mathrm{EI})$. One of the reasons regarding the obstacles to cooperation is that the MP3EI development principles do not pay attention to the physical or geographical conditions of Indonesia as a maritime country because most of them are still focused on developing projects on land (Mohamad, 2014). Supposedly, with the president's focal point, which tends to be more prominent in the land area, regulatory obstacles can be appropriately executed according to target. 
Meanwhile, Iceland uses geothermal energy as a more prominent player in a country's energy supply. The PLTP produced in 2004 was $17 \%$ of the total $8,618 \mathrm{GWh}$, and in 2009 it was estimated to be $20 \%$ or 15,000 GWh, of which $80 \%$ will be used in energy-intensive industries (Bjornsson, 2006). Iceland's interest in increasing geothermal energy is obtaining economic benefits from government policies, which can be seen when the total payment for hot water used for heating is compared to oil's consumer costs (Bjornsson, 2006). Geothermal's contribution has also influenced Iceland's prosperity from an environmental perspective because geothermal is an energy source that is less damaging to the environment than fossil fuels. After all, it does not emit CO2 into the atmosphere (Bjornsson, 2006). Then, the development of geothermal resources also has the expected impact on social life. The population of Icelanders is becoming preferring to live in areas where geothermal is available. The Master Plan developed by Iceland is strongly oriented towards Hydropower and Geothermal, which is being prepared by comparing the economic viability and the impact on the proposed electricity development project's environment. Some projects have been deemed to have environmental effects so severe that their development may not be acceptable.

Through the conditions of geothermal development in Iceland, it can be seen that there is a focus on the product that is still internal or domestic related to its economic and environmental interests. However, at the same time, it can also be seen from another point of view, that is, when internal problems are still being considered, economic improvement can be increasingly concentrated in the international realm through cooperation that has mutual benefits. In this case, it can be said that Iceland can make maximum use of its advantages in having experts and technology to provide training and direction to other technicians from other countries, especially Indonesia. 


\section{Political and Policy Barriers}

Indonesia's internal obstacle is that the government is faced with difficulties in managing and utilizing geothermal energy in protected or conservation forest areas. The wealth of geothermal spots has spread around $80 \%$ of Indonesia's geothermal reserves (International Geothermal Association, 2015) in the area. However, based on Law no. 27 of 2003, geothermal activities are categorized as mining, which means that the government has banned mining activities and processes in protected forest areas. The successful implementation phase can see the progress of cooperation in 2016 by KS ORKA in collaboration with PT. Sorik Marapi Geothermal Power in the Mandailing Natal area, North Sumatra (KS ORKA, 2019). Law No. 21/2014 has also been regulated that geothermal energy can be included in conservation forest areas using the geothermal environmental services utilization permit mechanism (IPJLPB). On this basis, the Forestry Law has been adjusted, starting from PP to Ministerial Regulation. Until now, a Minister of Environment and Forestry Regulation has been issued, which regulates how to issue geothermal environmental service permits or IPJLPB (Yulianugroho, 2019). The overlapping or out of sync regulations to intensify the development of geothermal energy has hampered PLTP development. Good governance failure can be seen from the continued increase in energy subsidies, especially electricity, from IDR 3 trillion to IDR 101 trillion in 10 years (2004-2014). Besides, Presidential Instruction Number 5 of 2006 concerning National Energy Policy targets an energy mix of $25 \%$ by 2025, but until 2014 it is still at $6 \%$ (Wicaksono, 2014).

The regulatory complexity in Iceland has a similar condition to Indonesia. However, many of the projects Iceland has undertaken internationally are mostly driven by individual companies and institutions. The efforts are integrated with strategies and action plans on how and where to focus should be emphasized, so designs should target potential partners, organizations, and financial institutions. This effort is set due to the nature of geothermal development and the importance of government funding and funding from international 
institutions so that close cooperation with Icelandic government agencies is required. Iceland's legal framework in geothermal energy is based on ownership of land resources attached to private land.

In contrast, the state owns public land resources unless other people can prove ownership rights. Although resource ownership is based on land ownership, research and use are subject to licensing under the Land Resources Survey and Utilization Law, No. 57/1998 (Law on Resources) and the Electricity Law, No. 65 / 2003. The Ministry of Industry and Innovation is the head organization of the energy sector in Iceland. The Ministry has two ministers, namely the Industry and Trade Minister and the Fisheries and Agriculture Minister. The Ministry has the powers of the Resources Act and the Electricity Act, which are the two main legal actions that form the basis of exploration and utilization of geothermal energy in Iceland. The obstacle to the implementation of geothermal cooperation has been identified by Alexander Richter (2016) in Mapping the Icelandic Geothermal Energy Sector. Several factors can correlate to the causes of hampering collaboration with Indonesia. Those are the weak strategy and joint action plans for international promotion covering all aspects of the sector from services, development, and operations to education; and both for electricity production and direct use of heating and cooling. In addition, there is also weak cooperation between relevant ministries and other government agencies in Iceland when questioning international efforts in the geothermal sector, which is very beneficial for the Icelandic geothermal industry (Richter, 2016). Thus, cooperation at the government level and creating a one-stop-shop for international relations to promote geothermal in general and the Icelandic sector's supply, in particular, is still weak. Funding is also minimal related to the global promotion and business development; participation in international research projects and the latest developments still need to be renewed for positive steps, so support is necessary to ensure Iceland's involvement.

The lack of official policies and plans that allow geothermal utilization in Iceland has also made it difficult for developers to plan future 
developments. This condition also shows that the lack of clarity is inhibiting the growth. The master plan the Icelandic government's proposed for hydro and geothermal energy sources is still under construction by the Icelandic government which is slated to clarify which areas will be available for future exploitation (Ketilsson, J., Petursdottir, H., Thoroddsen, S., Oddsdottir, A., Bragadottir, E., Gudmundsdottir, M., Johannesson, G., 2015). It can be seen from the technical obstacles related to regulations in Iceland. There are no regulations that discuss how to cooperate in geothermal development in Indonesia up to the operationalization stage of project development. There are still many internal (domestic) regulatory conditions that must be considered and coordinated in the government system. That way, obstacles to bilateral cooperation related to regulation are significant because a law can be the very foundation determining whether or not an international collaboration will occur.

The problems that we find have been emphasized by Siitonen (1990) that, as a consequence, the dynamics of cooperative development are conditioned by the interest in regulating the elite in society itself, since these elites are more dependent on foreign economic relations than their partners in other countries. The obstacles that occurred and should be overcome were to focus on elites who have interests in it who have committed to increasing geothermal development. All forms of corruption among elites in Indonesia and lack of financial or technical support from the government in Iceland can be executed well. All forms of internal obstacles that have not been resolved or found a solution will be a spillover to the international level, especially to establish international cooperation. A cooperation agreement will only be in black and white without any implementation stage, such as technical obstacles related to operations.

The signing of the MoU is a legal umbrella for cooperation between $P T$ Pertamina Geothermal Energy and Reykjavik Energy Invest (REI). Thus, the negotiation process becomes very significant to achieve the target implementation of the cooperation agreement. One of the hopes for cooperation from the Minister of Industry and Energy of Iceland, 
Ossur Skarpheoinsson, is that there is easy access to investing in geothermal energy in Indonesia with an estimated investment cost per MW of around US \$ 3-4 million. The big plan expected by the President Director of REI, Gudmundur Thoroddsson, is constructing a PLTP with a capacity of $500 \mathrm{MW}$ at an early stage (Tempo.co, 2007). According to the International Energy Agency (2008) in Pétursson (2011), the main obstacle that hinders Indonesia's geothermal development for power generation is the lack of law and contract certainty. Business confidence is based on this; unfortunately, investors are afraid of Indonesia. They don't trust the state, the law, or the PLN. The energy sector has identified a lack of clarity and transparency due to inconsistency, insufficient regulatory detail, and poor coordination between governments as the main problems hindering Indonesia's investment. Investors have expressed concern over the lack of legal certainty, difficulties negotiating and enforcing contracts, arbitration and giving judgments, and perceived unequal treatment of domestic versus foreign companies (Petursson, 2011).

The agreement between Indonesia and Iceland has decided that the actor who executes this cooperation is between The Ministry of Energy and Mineral Resources (MEMR) from Indonesia and The Ministry of Industry and Energy (MIE) from Iceland. The MoU policy decision was quite useful; however, the actors were too general, so that they took the form of a public ministry and less concentrated. Thus, each Ministry's policies can be less specifically directed at geothermal, which causes the implementation process to be hampered. Unfortunately, the diplomacy and negotiation processes that should have been carried out by PT PGE and REI were not as expected. There is an absence of a special agreement, or the Memorandum of Agreement (MoA) that specifically regulates cooperation in developing geothermal energy technically and in detail (Yulianugroho, 2019). In the absence of a world government, uncertainty about enforcement often arises in agreements between countries (Odell \& Tingley, 2013). Thus, it can be said that the weaknesses of Indonesia and Iceland have in common, namely in the regulatory aspect that comes from uncooperative governance. From the 
Indonesian side, the regulations produced by each authorized Ministry are out of sync in promoting geothermal development in Indonesia. Meanwhile, the regulations that encourage an international promotion strategy have been ignored by the cooperation between ministries and related government agencies from the Icelandic side.

\section{Zero Technology Transfer}

Iceland is one of the donor countries contributing to geothermal development in Indonesia through its various institutions and companies. Transfer of technology and information becomes the main thing besides financial assistance. Still, the difficulties usually found are interpreting and optimizing it, practical government control problems, language barriers, and technical issues related to marketing, payments royalty, guarantees, operator training, and others (Bard, 1971). In the process, Petursson (2011) has concluded that international cooperation through technology transfer has experienced obstacles due to the two parties' lack of performance in delivering information and implementing insufficient expert education activities.

The complexity that hinders technology transfer activities can also be caused by economic aspects, which have been emphasized by Carley \& Lawrence (2014), Haraldsson (2014), and Kirari, Adel, et al. (2018). However, it should be remembered that capital fulfillment is not the only crucial thing, but how policies that have been previously decided are related to regulations set and agreed upon in the country. Carley \& Lawrence (2014) have emphasized that several actors can strengthen geothermal development, such as government officials, communities, community development practitioners, industry and business leaders, and representatives from non-profit organizations, who collaborate to form a more robust network. Meanwhile, Haraldsson (2014) has focused more on economic development to support other countries' shortages through direct support in developing countries in technical to risk financing. The private sector's role and overcoming obstacles, especially in rural financing electrification, can also cause obstructions themselves (Kirari, Adel, Andria, Lakaseru, 2018) due to the absence of 
financial assistance from the government, which ultimately cannot continue exploration or exploitation activities.

When talking about technology transfer, it will also be related to the need for high quality and skilled human resources to support Indonesia's geothermal development. Assuming that 30-50 people per year are needed to support 1,00o MW geothermal development in Indonesia, to develop $4733 \mathrm{MW}$ in Indonesia by 2014, Indonesia will need at least 120 people per year, including engineers and geothermal scientists (Saptadji, 2010). This number does not include the number of people required to explore 163 geothermal areas currently still in the preliminary survey stage and for further exploration in 78 regions, which in 2010 were still in the exploration stage (Saptadji, 2010). Pertamina Geothermal Energy (PGE), which the government entrusted to implement this cooperation, has proven that there will be no separate agreement except for human resources training to Iceland since 1982. They were trained to obtain and improve knowledge related to utilization until geothermal energy management (Yulianugroho, 2019).

Besides, PGE has also implemented a collaboration applied in an annual program called the International Geothermal Convention and Exhibition, which includes speakers from Iceland (Yulianugroho, 2019). So, you can imagine if the delivery of human resources per year can be maximized and reach the targeted number, less than 2014, there can be a significant increase in geothermal capacity implementation. Therefore, the number of human resources sent by PT PGE reflects the minimal development of geothermal energy in Indonesia from 20072014. Weak regulations have had a further impact on this stage of technology transfer. This situation is because, in essence, although the national government plays a dominant role in energy governance, challenges that are beyond the scope of the national government that must be managed make energy policy a significant component of global governance and international relations (Florini \& Dubash, 2011). 


\section{Technical Barriers}

Based on the four points described by Adam Mazurkiewicz \& Beata Poteralska (2016) regarding obstacles that are likely to affect technology transfer, it can be underlined that there is a technological gap. The technology in Iceland is way too sophisticated compared to Indonesia. There are conditions of geothermal development in Iceland that are more advanced, not only indirect utilization but also direct utilization, which has been successfully applied, especially for Greenhouse Farming. Direct utilization must use specific methods different from turbines. Unfortunately, there has been no further discussion until now because the turbines are customized or based on orders with individual specifications that require consideration aftersales spare parts. There are still explorations because Iceland has been more advanced in developing its geothermal energy (Yulianugroho, 2019).

Mazurkiewicz \& Poteralska (2016) explain the second point of organizational-economic barriers: the differences in characteristics that occur can be underlined in the elements 'cost contribution, internal structure, and experience' the causes. The three of them have a domino effect that ultimately raises barriers to technology transfer. For Iceland, its internal structure related to geothermal development is quite useful due to the emergency conditions it experienced in the 1970s due to the massive oil crisis so that automatically the government has fully supported the cost of developing geothermal energy. It is not surprising that their experience is also very professional, as evidenced by the quality and quantity that are now successfully utilized through the rapid development of the expertise and technology used. Meanwhile, for Indonesia, the government's orientation is still not entirely focused on developing geothermal energy as a substitute for the depleting energy sources, so it still relies heavily on foreign investors. Besides, internal structures such as the Ministry with inconsistent provisions hamper the smooth running of cooperation, especially in exploration and exploitation activities. Their experience is less honed and quality guaranteed. Even though they have carried out knowledge in Iceland, 
the trained human resources will still have problems in the exploration process implementation.

On the other hand, the absence of a technology development plan at the national level, because public decision-making powers cannot create conditions for the coherent promotion, support, and targets for public and private R\&D and innovation (Mazurkiewicz \& Poteralska, 2016) could be the cause. The lack of coordination between authorities in decision-making has a significant impact on the development of technology needed for exploring activities. It can be seen from Indonesia, which is still struggling with geothermal-related regulatory issues that have been discussed in the previous chapter. Bojang AS (2018) has emphasized that two thoughts argue that domestic politics and foreign policy are two independent 'problems,' while others think that foreign policy and internal politics are 'interdependent' and can collide. In some cases, international factors play a significant role, while domestic determinants are more important in other cases. So that in the end, the impact generated agrees with the fourth point regarding system barriers by Mazurkiewicz \& Poteralska (2017), that lobbying, or interest groups effectively inhibit changes and improvements in the legal system, making technology transfer impossible or inefficient. They are not at all able to support the development of technology in Indonesia.

\section{CONCLUSIONS}

The complexity of regulations and technology gaps that result in the absence of technology transfer are the two main obstacles to IndonesiaIceland cooperation. This condition can be proven by each country's internal issues that have become sources of barriers to cooperation development. Indonesia, which has ministries with unsynchronized regulations, even overlaps, so that until 2014 no constraint could execute this issue. At the same time, Iceland struggles with the weakness of a joint strategy and action plan for international promotion, weak cooperation between relevant ministries and other government agencies. Hence, no regulation discusses how to cooperate in 
Indonesia's geothermal development to the operationalization stage of project development. The technology gap is another thing to consider because it has hampered the technology transfer process's smooth operation.

The first, second, and third points in the MoU have been implemented but have not been explored in more depth, significantly, and are still very minimal than what is needed by Indonesia to achieve the expected targets. Meanwhile, other points fall under the obstacles to cooperation between Indonesia and Iceland in developing geothermal energy in Indonesia in 2007-2014. In general, the barriers experienced are in constructing the geothermal development project itself, namely exploration, exploitation, and utilization or operation. These three main activities are the result of a technological gap. On one side, Iceland is more advanced in technology ownership. It is still very much considered for transferring technology from Iceland to Indonesia in terms of financing to the risk that it will be a large number of state losses if it occurs. Domestic governance makes international cooperation and the agreements made in the MoU unable to be fully implemented.

Therefore, to overcome the obstacles to implementing joint exploration, the Government of Indonesia must work closely with the private sector to reduce geothermal exploration's inherent risks early in the process. The state-owned geothermal developer (Pertamina Geothermal Energy) must be given greater autonomy, budget, and mandate to explore and develop geothermal energy. Likewise, with Iceland, Indonesia must have firm regulations or provisions related to international cooperation in geothermal energy. Moreover, after it is known that Iceland has experienced global promotion should be carefully formulated through the most effective strategy. 


\section{REFERENCES}

Bard, B. J. (1971). The Transfer of Technology. Acta Oeconomica, Vool. 6, No. 1/2, 37-44.

Bjornsson, S. (2006). Geothermal Development and Research in Iceland. Reykjavik: National Energy Authority and Ministries of Industry and Commerce.

Bojang AS (2018). The Study of Foreign Policy in International Relations. J Pol Sci Pub Aff 6: 337. doi:10.4172/23320761.1000337

Caldés N., Rodriguez I., Lechon Y., del Río P. (2018). Analysis of the barriers to the use of the cooperation mechanisms for renewable energy in the EU. Deliverable 4.1, MUSTEC project, CIEMAT, Madrid.

Carley, S. \& Lawrence, S. (2014). How Clean Energy can Drive Development and Stimulate Economic Growth. Verlag, London: Springer.

Embassy of Indonesia. (2014, April 8). Indonesia-Iceland. Dari Embassy of the Republic of Indonesia, Oslo, Norway: http://indonesia-oslo.no/indonesia-iceland/

Embassy of Indonesia. (2019, September 15). Indonesia - Iceland. Dari Indonesia - Oslo: http://indonesia-oslo.no/indonesia-iceland/

Florini A. \& Dubash N. K. (2011). Introduction to the Special Issue: Governing Energy in a Fragmented World. Global Policy Volume 2. Special Issue. , 1-5.

International Geothermal Association. (2015, Oktober 1). Geothermal Energy. Dari Indonesia Investments: https://www.indonesiainvestments.com/business/commodities/geothermalenergy/item 268

IRENA. (2017). Renewable Energy Prospects: Indonesia, a REmap analysis. Abu Dhabi: International Renewable Energy Agency.

ÍSOR . (2017, August 10). Visit from Indonesian Delegation. Dari ÍSOR Iceland Geosurvey: http://en.isor.is/news/visit-indonesiandelegation 
kabarbisnis. (2011, Desember 19). Perizinan Proyek Panas Bumi Dipermudah. Dari kabarbisnis:

https://www.kabarbisnis.com/read/2825164

KESDM. (2010). Deklarasi Bali: Geothermal Energy to Change the World. Dari Ministry of Energy and Mineral Resources Republic of Indonesia: https://www.esdm.go.id/en/media-center/arsipberita/deklarasi-bali-geothermal-energy-to-change-the-world KESDM. (2010). Islandia: Negeri Es yang Sukses Kembangkan Panas Bumi. Dari Kementerian Energi dan Sumber Daya Mineral Republik Indonesia : https://www.esdm.go.id/id/mediacenter/arsip-berita/islandia-negeri-es-yang-sukses-

kembangkan-panas-bumi

Ketilsson, J., Petursdottir, H., Thoroddsen,S., Oddsdottir, A., Bragadottir, E., Gudmundsdottir, M., Johannesson, G. (2015). Legal Framework and National Policy for Geothermal Development in Iceland. Proceedings World Geothermal Congress 2015, 1-12.

Kirari, Adel, Andria, Lakaseru. (2018). Supporting Indonesia's Renewable Energy Development in Remote and Rural Areas through Innovative Funding. Indonesia Development Forum , 115.

KS ORKA. (2019). KS ORKA . Dari KS ORKA Fully Established in Indonesia: https://ksorka.com/ks-orka-fully-established-inindonesia/

Mazurkiewicz A. \& Poteralska B. (2017). Technology Transfer Barriers and Challenges Faced by R\&D Organisations . Procedia Engineering 182 , 457-465.

Milner, H. (1992). International Theories of Cooperation Among Nations: Strengths and Weaknesses. World Politics, 44, 446-496. Mohamad, A. (2014, September 19). Jika lanjutkan program SBY, Jokowi tak beda dari Prabowo. Dari merdeka.com: https://www.merdeka.com/uang/jika-lanjutkan-program-sbyjokowi-tak-beda-dari-prabowo.html

Odell, J. \& Tingley, D. (2013). Negotiating Agreements in International Relations . American Political Science Association, 144-182. 
Petursson, H. (2011). Geothermal Development in Indonesia Institutional Barriers and Opportunities for Icelandic Technology Transfer. International Business and Politics, 1-92.

Richter, A. (2016). Mapping the Icelandic Geothermal Energy Sector. Iceland: Islandsstofa.

Saptadji, N. M. (2010). Geothermal Education for Supporting Geothermal Development in Indonesia . Proceedings World Geothermal Congress 2010, 1-6.

Siitonen, L. (1990). Political Theories of Development Cooperation - A Study of Theories of International Cooperation. World Institute for Development Economics Research of the United Nations University, 1-78.

Sugiyono. (2008). Metode Penelitian Kuantitatif Kualitatif dan R\&D . Bandung: Alfabeta.

Sukhyar, R. (2010, April 26). Indonesia Sebagai Pusat Keunggulan Panas Bumi. From Kementerian Energi dan Sumber Daya Mineral Republik Indonesia: https://www.esdm.go.id/id/mediacenter/arsip-berita/indonesia-sebagai-pusat-keunggulan-panasbumi

Tempo.co. (2007, Oktober 23). Indonesia-Islandia akan Bangun Pembangkit Listrik Panas Bumi. Dari Tempo.co: https://bisnis.tempo.co/read/109992/indonesia-islandia-akanbangun-pembangkit-listrik-panas-bumi

Wicaksono, P. E. (2014, Oktober 18). Ini Kegagalan Pemerintahan SBY di Sektor Energi. Dari Liputan6: https://www.liputan6.com/bisnis/read/2120831/ini-kegagalanpemerintahan-sby-di-sektor-energi

Yulianugroho, S. (2019, Desember 5). Hambatan Kerja Sama Indonesia-Islandia dalam Pengembangan Energi Panas Bumi di Indonesia tahun 2007-2014. (A. S. Bestari, Interviewer) 